\title{
КРИЗИС ПОДДЕРЖКИ ПАРТИИ СМЕР - СОЦИАЛЬНАЯ ДЕМОКРАТИЯ В 2017-2018 ГГ.
}

\begin{abstract}
Аннотация. В данной статье анализируется динамика электоральной поддержки партии Смер - социальная демократия (С-СД), левоцентристской партии, которая занимает лидирующие позиции в Словакии со времени парламентских выборов в 2006 г. Наша цель установить, сможет ли данная партия удержать позиции и остаться сильнейшей политической силой страны ещё на один срок. Развитие партии изучается в контексте так называемых «выборов второго порядка», проведенных в Словакии в ноябре 2017 г. (региональные выборы) и в ноябре 2018 г. (выборы местного самоуправления). В обоих случаях их результат показал существенное снижение народной поддержки С-CД. Однако это не означает усиления правоцентристской оппозиции. Поэтому, несмотря на признаки внутрипартийного кризиса, С-СД до сих пор остается влиятельной партией в Словакии и пользуется самым высоким уровнем поддержки среди населения. С-СД обладает некоторыми свойствами «предоминантной» партии, однако ей всегда (за исключением периода с 2012 по 2016 гг.) приходилось искать партнеров по коалиции. Поэтому она никогда не была таковой полностью и, принимая во внимание динамику поддержки электората, не сможет стать ею в обозримой перспективе.

Ключевые слова: Словакия, политические партии, социал-демократия, Смер - социальная демократия, Смер-СД, выборы второго порядка.

Досрочные выборы в Национальный Совет Словацкой Республики (НС CP) в марте 2012 г. закончились победой партии Смер - социальная демократия (Smer sociálna demokracia, C-CД), которая заручилась поддержкой 44,44\% голосов избирателей. Вторая по величине партия - Христианско-демократическое движение (Krest'anskodemokratické hnutie, ХДД) - получила 8,81\%. Лидирующая позиция ССД укрепилась также вследствие потери голосов партий, которые не попали в парламент. Так, она приобрела в НС СР больше половины мандатов $(55,3 \%$, что составляло 83 из 150 кресел) [The Election to the Parliament...]. Результатом стало то,
\end{abstract}

(С) Марушьяк Юрай - старший научный сотрудник Института политических наук Словацкой академии наук. Aдpec: 84104, Словакия, Братислава, ул. Дубравска цеста, 9. $\boldsymbol{E}$-mail: marusiak@up.upsav.sk

Статья была подготовлена в рамках проекта VEGA 2/0007/16 „Elections 1946 and Elections 2016 in Slovakia“.

Современная Европа, 2018, № 7 
что председатель партии Роберт Фицо был избавлен от необходимости искать коалиционного партнера.

Одновременно выборы 2012 г. привели к фрагментации правоцентристских сил. Словацкий Демократический и Христианский Союз - Демократическая Партия (SDKÚ-DS, CДХC-ДП) потеряла доминирующие позиции после десятилетия лидерства на этом фланге. Она была главным инициаторам неолиберальных экономических реформ после 2002 г. В 2012 г. она получила только 6,09\% голосов избирателей. Среди оппозиционных партий ее обошла даже возникшая незадолго до выборов консервативная партия Обыкновенные люди и независимые личности (Obyčajní l’udia a nezávislé osobnosti, ОЛиНЛ, 8,55\%), в рядах которой присутствовали и независимые кандидаты, принадлежащие к разным идеологическим направлениям. Фрагментация правоцентристского фланга была последствием коррупционного скандала «Горилла» 1 . Его суть заключалась в том, что появившиеся документы Словацкой информационной службы свидетельствовали, что в ходе приватизации СДХС-ДП использовала свои полномочия для поддержки финансовой группы «Пента». В свою очередь это позволило обеспечить парламентское большинство партии после распада депутатской фракции Альянс нового гражданина (Aliancia nového občana, AHO) и ухода части депутатов из фракции СДХС-ДП в 2002-2006 гг. Следующим важным следствием парламентских выборов в 2012 г. стала маргинализация значимости этнических факторов, которые в Словакии после 1993 г. в значительной степени влияли на структурирование политических союзов и процесс создания правительственных коалиций. В НС СР не попала ни Партия венгерской коалиции (Strana mad'arskej koalície, ПВК) ${ }^{2}$, которая довольствовалась 4,28\%, ни Словацкая национальная партия (Slovenská národná strana, СНП) с 4,55\% [The Election to the Parliament]. Обе политические силы строили свою идентичность на основе этнического принципа. С 2010 г. венгры в Словакии представлены в парламенте только партией Мост-Хид (Most-Híd), которая ориентируется на сотрудничество со словацким большинством $(6,89 \%)$.

Победа партии С-СД в 2012 г. является беспрецедентным феноменом в словацкой политике со времен падения коммунистического режима в 1989 г. Впервые политическая партия получила в НС СР абсолютное большинство и смогла создать правительство без поддержки какого-либо коалиционного партнера. Одновременно результаты выборов означают крупнейший политический успех $\mathrm{C}-\mathrm{CД}$ с момента ее основания в 1999 г.

Однако более интересен анализ развития электоральной поддержки партии $\mathrm{C}-$ СД после успеха 2012 г. Наша цель состоит в том, чтобы ответить на вопросы приобрела ли партия, которая с 2006 г. получала на парламентских выборах первое место (см. табл. 1), характер так называемой предоминантной партии (pre-dominant party) и в какой степени она может сохранить позицию сильнейшей политической

\footnotetext{
${ }^{1}$ См. подробнее: Nicholson T. Gorila. Bratislava: Dixit, 2012.

${ }^{2}$ В сентябре 2012 г. Партия венгерской коалиции была переименована в Партию венгерского сообщества.
} 
силы в будущем? Данные вопросы анализируются в контексте результатов так называемых выборов второго порядка. Имеются в виду выборы в органы регионального самоуправления в ноябре 2017 г. и муниципальные выборы, которые состоялись в ноябре 2018 г. Весной 2018 г. в Словакии произошёл политический кризис в связи с убийством журналиста Яна Куциака и его невесты, который сопровождался массовыми протестами против правительства Р. Фицо [Ведерников, 2018: 72]. Они прошли не только в Братиславе, но и в других словацких городах. Поэтому наша следующая цель - идентифицировать, в какой степени можно говорить о создании альтернативы, имеющей возможность заменить С-СД после парламентских выборов, назначенных на март 2020 г.

Таблица 1.

Динамика электоральной поддержки партии С-СД в 2002-2016 гг. (выборы в Национальный Совет Словацкой Республики)

\begin{tabular}{|l|c|c|c|c|c|}
\hline \multicolumn{1}{|c|}{ Год } & 2002 & 2006 & 2010 & 2012 & 2016 \\
\hline $\begin{array}{l}\text { Результат } \\
\text { (\% голосов) }\end{array}$ & 13,46 & 29,14 & 34,79 & 44,41 & 28,28 \\
\hline $\begin{array}{l}\text { Количество } \\
\text { мандатов }\end{array}$ & 5 & 50 & 62 & 83 & 49 \\
\hline Место & 3-е & 1-е & $1-\mathrm{e}$ & $1-\mathrm{e}$ & $1-\mathrm{e}$ \\
\hline
\end{tabular}
public.

Под понятием «система предоминантной партии» (pre-dominant party) подразумевается такая партийная система, в которой существует политическая партия, которая на протяжении длительного срока получает больше голосов, чем все остальные. Джованни Сартори считает также, что такая партия должна долговременно иметь абсолютное большинство мандатов в парламенте [Sartori, 2005]. Однако в отличие от системы одной политической партии (single party) или системы гегемонической партии (hegemonic party) правящая партия не ставит под сомнение демократический характер политического режима. Таким образом, другие политические партии могут свободно действовать и сместить её в результате свободных выборов.

Так называемые «выборы второго порядка» не определяют структуру законодательной и исполнительной власти на национальном уровне. Они также не влияют на состав словацких депутатов в Европейском парламенте [Šaradín, 2007: 9-10]. Учитывая масштаб вопросов, находящихся в ведении самоуправления, эти выборы представляют меньший интерес как для избирателей, так и для политических партий. Помимо этого, К. Райф и Г. Шмитт [Reif and Schmitt, 1980: 3-44] приводят следующие характеристики региональных выборов: поддержка партий, находящихся у власти, во время региональных выборов ниже по сравнению с общенациональным волеизъявлением, что приводит к усилению малых и новых партий; избиратели в большей степени руководствуются собственными предпочтениями, нежели ориентируются на установки конкретных партий; по сравнению с общенацио- 
нальными выборами предвыборная кампания играет бо́льшую роль для мобилизации избирателей. С одной стороны, избиратели голосуют за партии, чьи кандидаты схожи с кандидатами на выборах первого порядка. С другой стороны, выборы второго порядка могут быть стратегически мотивированы с целью «наказать» текущее правительство [Binzer Hobolt and Wittrock, 2011: 31]. Таким образом, результаты выборов второго порядка могут совпадать с выборами первого порядка, т. е. парламентских и президентских выборов в Словакии, запланированных на весну 2019 г.

Смер - социальная демократия в 2012-2016 z2.

Успех партии Смер - социальная демократия в 2012-2016 гг. заключается в том, что в отличие от оппозиционных правоцентристских партии она не была подвержена дезинтеграционным тенденциям. На левой стороне политического спектра не возникли релевантные конкурентные проекты, которые могли бы представлять для нее угрозу. Премьер-министр Р. Фицо сохранил высокий уровень поддержки населения. Среди экономических и социальных реформ можно назвать введение элементов прогрессивного налогообложения. В 2012 г. был увеличен налог с 19 до $23 \%$ для юридических и физических лиц с высокими доходами [Malová and Učeň, 2013]. В 2015 г. понизился НДС с 20 до 10 \% на основные продовольственные товары. В 2014 г. правительство ввело бесплатные железнодорожные проездные для студентов и пенсионеров, инвалидов и лиц, получающих пособие по потере кормильца. Фактор успеха заключался и в существенном усилении экономики. В 2014 г. рост ВВП составил 2,4 \%; в 2015 г. безработица упала до 10,6 \% (в 2013 г. она находилась на уровне 14\%) [Správa o krajine...]. Критика со стороны оппозиции концентрировалась на вопросах, связанных с коррупцией и дискриминационной проблематикой [Malová and Učeň, 2014].

В контексте Центральной Европы политический успех С-СД можно сравнить с победой партии «Право и Справедливость» в Польше в 2015 г. или с успехом блока ФИДЕС - Христианско-демократическая народная партия (ФИДЕС - ХДНП) в Венгрии, который сохраняет доминантную позицию с 2010 г., победив на парламентских выборах в 2014 и в 2018 гг. В отличие от упомянутых партий C-CД не использовала парламентское большинство для внедрения государственного контроля над общественными СМИ или для ограничения полномочий судебной власти и других органов общественного контроля. Первым вызовом для доминантной позиции С-СД на политической сцене стали региональные выборы в регионе Банска Быстрица, которые закончились победой лидера правоэкстремистской Народной партии - наша Словакия (Ludová strana - Naše Slovensko, HП-HC) Мариана Котлебы во втором туре над кандидатом С-СД Владимиром Маньком. Котлеба открыто выражает свои симпатии режиму фашистского Словацкого государства в 19391945 гг. Он стал известен широкой публике организацией демонстраций против членов цыганского меньшинства в Словакии. Следующим провалом С-СД были президентские выборы в марте 2014 г., в которых при поддержке оппозиционных партий во втором туре победил независимый кандидат Андрей Киска в соотноше- 
нии 59,38\% против 40,61\% голосов [Referendum, 2015]. Кроме повышения значимости социальной политики, отличительной чертой новой избирательной кампании стало усиление праворелигиозных взглядов. Под их давлением парламент, благодаря поддержке С-СД и ХДД, одобрил преамбулу Конституции Словацкой республики, согласно которой браком можно считать только союз мужчины и женщины. Однако референдум, инициированный по данному вопросу провалился, из-за недостаточного участия избирателей $(21,41 \%)^{1}$.

Летом 2015 г. главной темой общественной дискуссии стал вопрос о приеме беженцев. Словацкое правительство во главе с Р. Фицо упорно отказывалось соглашаться с квотированным и обязательным распределением мигрантов среди стран членов ЕС. В этой связи С-СД вступила в конфликт и с некоторыми социалдемократическими партиями Западной Европы. Выступления премьера, в которых он предостерегал от возникновения «компактного мусульманского сообщества» [Musíme zabránit’...] в Словакии, вызвали негативную реакцию со стороны социалистических и социал-демократических партий, особенно во Франции, Голландии, Бельгии и Италии [Kern, Tóda, 2015]. Защита национальных интересов была озвучена как ключевой приоритет и во время визита президента Чехии Милоша Земана 12 февраля 2016 г. Несмотря на эмоциональную окраску, которая сопровождала освещение проблематики беженцев со стороны политических партий, в начале 2016 г. этот вопрос оказался на втором плане после забастовок учителей и медицинских сестер, которые требовали повышения заработной платы. Эти протесты встретили одобрение у правоцентристской оппозиции. Руководство С-СД не было подготовлено к такому повороту событий, и его реакция была соответствующей. На передний план следующей избирательной кампании выдвинулись коррупционная проблематика и вопросы состояния образовательной системы и здравоохранения.

Парламентские выборы в марте 2016 г. не смогли удержать позицию С-СД. Между тем, она получила больше мандатов, чем другие политические партии. Страх перед беженцами из стран так называемого третьего мира не повлиял на консолидацию электората вокруг C-СД, которая в ходе избирательной кампании сменила ключевой, социально ориентированный лозунг «Мы работаем для людей» на национально мотивированный «Мы защищаем Словакию». В то же время в Национальный Совет СР попали политические партии с антииммигрантской риторикой, как, например, правоэкстремистская НП-НС. Значительный успех имела и евроскептическая партия «Свобода и Солидарность» (Sloboda a Solidarita, СиС), которая тоже пользовалась антииммигрантской риторикой. Именно она стала в 2016 г. главной оппозиционной партией Словакии. Кроме консервативных партий на выборах добились успеха и силы, которые отказывались от традиционной модели политики, как, например, партия ОЛиНЛ или «Мы - семья». Ее лидер миллионер Б.

\footnotetext{
${ }^{1}$ Признание референдума в Словакии возможно при наличии кворума в $50 \%$ избирателей. Также обсуждались вопросы, касающиеся запрета на усыновление детей парами или группами лиц одного пола и введения факультативного предмета по сексуальному воспитанию в школах.
} 
Коллар во время кампании подчеркивал, что в отличие от своих соперников он не является политиком.

Хотя партия СиС имела амбиции создать правительство без С-СД, при участии или одобрении широкого спектра оппозиционных сил (СиС, ОЛиНЛ, Мост-Хид, Сеть, Мы - семья, СНП), результатом переговоров после выборов стало формирование коалиционного правительства, состоящего из С-СД, СНП, Мост-Хид и Сети. Это означало значительный сдвиг словацкой политической традиции, утвердившейся после 1993 г. Во-первых, в коалицию с С-СД вошли правоцентристские партии Мост и Сеть, которые ранее от такой альтернативы отказывались. Это привело к концу изоляции С-СД со стороны правоцентристов, которая продолжалась с 2006 г. Во-вторых, она впервые вошла в коалицию с партией, которая представляла интересы венгерского меньшинства. В-третьих, выборы подтвердили продолжение тенденции к маргинализации раздела по этническому принципу, поскольку в коалицию одновременно вошли Словацкая национальная партия и представители венгерского электората.

\section{Выборы в органы регионального самоуправления}

Выборы в органы регионального самоуправления отличаются особыми правилами по сравнению с парламентскими выборами. Они организованы по мажоритарному принципу в нескольких мандатных избирательных округах. Главу региона (samosprávny kraj) избиратели выбирают напрямую на 4-летний срок.

Начиная со второй избирательной кампании в органы регионального самоуправления 2005 г., кандидаты на пост глав краев от С-СД и независимые кандидаты, поддерживаемые данной партией, оказались более успешными, чем кандидаты от правоцентристских партий. В 2005 г. шесть из восьми руководителей регионального самоуправления были избраны при поддержке С-СД. В 2009 и 2013 гг. уже 7 из 8 кандидатов от С-СД получили данные посты. В определенной степени можно говорить об успехе партии на региональных выборах в 2001 г., когда в 6 случаях из 8 главой края стали оппозиционные кандидаты. На тот момент кандидаты, в основном, представляли «Народную партию - движение за демократическую Словакию» (L'S-HZDS). Однако позднее значительное число её представителей, как на региональном, так и на национальном уровне, сблизились с С-CД (например, Тибор Микуш в Трнавском крае, Милан Белица в Нитранском крае и Петер Чудик в Прешовском крае). Также следует отметить и то, что предвыборные кампании на региональном уровне были главным образом сосредоточены на получении поста главы края. Из данных фактов вытекает, что С-СД на протяжении длительного времени пользовалась в органах регионального самоуправления, за исключением Братиславского региона, стабильной поддержкой, которая соответствовала результатам, полученным ею на парламентских выборах. Также итоги народного волеизъявления соответствовали результатам парламентских выборов в данных субъектах. Так, например, в Южной Словакии выборы подтвердили лидирующую позицию партий, представляющих венгерское меньшинство; в больших городах, таких как Братисла- 
ва или Кошице, голосование показало стабильную поддержку правоцентристских партий.

Правительственная коалиция, из которой вышла партия Сеть, распавшаяся в течение первых месяцев 2017 г. и большинство депутатов которой поддержали партию Мост, выступала на региональных выборах неконсолидированно [Poslankyn̆a Alena Bašistová...]. Коалиционные партнеры действовали совместно только в регионе Нитра и Тренчин, что свидетельствовало об их слабой сплоченности. В столичном Братиславском регионе C-СД официально не поддержала ни одного кандидата на пост его главы. В свою очередь оппозиционные правоцентристские партии действовали на региональных выборах 2017 г. совместно. Три крупнейшие правоцентристские партии (СиС, ОЛиНЛ и ХДД) вместе с небольшими партиями создали предвыборные блоки во всех регионах Словакии. Специфическая ситуация возникла в регионе Банска Быстрица, где коалиционные и оппозиционные силы объединились, поддержав независимого кандидата Яна Лунтера, у которого были самые большие шансы победить лидера НП-НC Мариана Котлебу [Vražda D., 2017].

Региональные выборы 4 ноября 2017 г. характеризовались самой высокой явкой на выборах этого типа с момента их введения в 2001 г. В них участвовало 29,95\% избирателей [The Elections to the Bodies...].

В 2013 г. 6 избранных глав регионов из 8 пользовались поддержкой С-СД (пост главы Банска-Быстрицкого края занял Мариан Котлеба), а главой Братиславского края стал Павол Фрешо, ставленник правоцентристской коалиции - Демократической партии, Христианско-демократического движения, Мост-Хид, СиС и других малых партий. В 2017 г. только два кандидата от С-СД выиграли выборы: Милан Белица в Нитранском крае и Ярослав Башка - в Тренчинском крае, в регионах, где они были поддержаны партнерами С-СД по коалиции. Премьер-министр и лидер $\mathrm{C}-\mathrm{CД}$ Роберт Фицо нанес визит в Жилинский край непосредственно перед выборами, но даже этого оказалось недостаточно, чтобы кандидат от С-СД одержал победу [Prušová, V., 2017]. Напротив, кандидаты от оппозиционного блока правоцентристских партий успешно провели кампании в пяти регионах, а главой БанскаБыстрицкого края стал независимый кандидат Ян Лунтер, поддержанный как правящей коалицией, так и правоцентристскими силами. Несмотря на то что $\mathrm{C}-\mathrm{CД}$ сохранила за собой наибольшее число депутатов в региональных парламентах (89) среди всех политических партий, их общее число упало более чем на треть (во время предыдущего срока в региональных парламентах состоял 151 депутат) [The Elections to the Bodies...]. Второе и третье место заняли не входящие в парламент партии ХДД (46 членов) и Партия венгерской коалиции (33 члена) соответственно благодаря сильным региональным структурам. ПВК обошла партию Мост-Хид, которая заняла только 10 мест в региональных парламентах. Слабые результаты показали вторая по силе парламентская партия СиС (15 депутатов) и ОЛиНЛ (23 депутата), на что, возможно, повлияло недостаточное развитие региональных организаций партии (в случае с СиС) или и вовсе их отсутствие (в случае с ОЛиНЛ). 
С-СД увеличил число депутатов только в Братиславском крае (с 1 в 2013-2017 гг. до 5 после 2017 г.), но количество представителей в остальных регионах существенно сократилось. Самое большое сокращение числа депутатов С-СД произошло в Трнавском крае, где их количество уменьшилось с 12 до 1. Что касается региональных парламентов, то правящая коалиция превосходит партии правого спектра в Нитранском (17 против 10), Банска-Быстрицком (17 против 4), Тренчинском (16 против 9) и Кошицком краях (23 против 15). В остальных регионах правая оппозиция имеет больше депутатов в региональных парламентах, чем правящая коалиция.

Согласно официальным результатам выборов, от общего числа депутатских мест наибольшее число мандатов получили независимые кандидаты (161 место), Однако согласно данным портала Денник Н, который выявил партийную принадлежность кандидатов на основании заявлений участвующих в выборах партий и коалиций, число независимых депутатов составляет 165 человек [Koník J., 2017]. C точки зрения партийной принадлежности избранных кандидатов независимые представляют наибольший сегмент, что может вызвать проблему при формировании стабильного большинства в региональных парламентах, так как их поведение трудно предугадать. Также нельзя исключать факта, что кандидаты, официально указанные независимыми, были членами политических партий, но не смогли попасть в коалиционную квоту, потому что партиям приходилось делить места избранных кандидатов с партнерами по коалиции. Сообщалось также и о внутренних конфликтах в С-СД. Сразу после выборов заместитель главы партии и министр культуры Словакии Марек Мадярич призвал к «существенным изменениям в партии ... относительно её политики, повестки и кадрового состава», назвав их результаты поражением партии [Minister Mad'arič... 2017]. Заместитель премьер-министра и вице-председатель партии Петер Пеллегрини также частично раскритиковал результаты народного волеизъявления [Smer-SD stratil dominanciu... 2017]. С критикой кадровой политики партии выступил Ян Подманицкий, член парламента от ССД и сторонник её консервативной фракции [Fico je po porážke... 2017].

Лидер C-СД Роберт Фицо отказался признавать итоги выборов как поражение его партии, напротив, заявив о «полной победе». После того как Мадярич раскритиковал текущую политику C-СД, но не смог заручиться поддержкой руководства партии, он официально объявил о своем уходе с поста заместителя главы партии, при этом сохранив министерский портфель [Mad’arič končí... 2017]. Он также pacкритиковал действия партии по отношению к органам регионального самоуправления на партийной конференции 9 декабря 2017 г. Его замечания затрагивали деятельность партии в Братиславском крае, где C-СД не нашла кандидата, которого партия могла бы поддержать. Он потребовал от коллег проанализировать ситуацию и внес предложение о создании площадки для обмена мнениями. Лидер региональной организации $\mathrm{C}-\mathrm{CД}$ Мартин Гивач осудил речь Мадярича. После региональных выборов, С-СД усилила кампанию по конфронтации с оппозицией и критике интеллигенции (так называемым Братиславским кафе) [Sliz M., 2017], но также сфокусировав внимание на социальных вопросах. Роберт Фицо, напротив, подтвердил 
социально-консервативное направление развития партии, заявив, что С-СД останется словацкой, а не брюссельской социал-демократией.

Региональные выборы можно однозначно характеризовать как электоральное поражение C-СД, крупнейшее с парламентских выборов в 2002 г., когда эта партия заняла 3-е место (см. табл. 2). Неблагополучный конец 2017 г. и начало 2018 г. были усугублены заявлением министра иностранных и европейских дел Мирослава Лайчака, который отказался баллотироваться на президентских выборах 2019 г. [Matišák A., 2018], несмотря на то, что Р. Фицо несколько раз называл его потенциальным кандидатом от партии.

\section{Динамика развития электоральной поддержки Смер - социальная демократия}

Убийство журналиста Яна Куциака и его невесты Мартины Кушнировой 21 февраля 2018 г. вызвало многочисленные протесты граждан не только в Братиславе, но и в других городах Словакии. Митингующие требовали проведения досрочных парламентских выборов. Это требование поддерживала не только гражданская инициатива «За достойную Словакию» (Za slušné Slovensko), но также оппозиционные партии и президент страны Андрей Киска [Takáč А., 2018]. Информация о связи членов кабинета правительства Словацкой республики и приближенных премьер-министра Р. Фицо с итальянской мафией привела к конфликту внутри коалиции.

Хотя С-СД осталась у власти и после кризиса, Р. Фицо был вынужден подать в отставку. Новым премьер-министром стал заместитель председателя партии Петер Пеллегрини [Ведерников, 2018: 75]. Политический кризис показал наличие внутрипартийных конфликтов. С должности министра культуры ушел в отставку в знак несогласия с политикой руководства бывший заместитель председателя партии и один из её основоположников, Марек Мадярич [Bariak, L. ml...]. Он заявил, что больше не будет поддерживать правительственную коалицию. Это был первый подобный случай в истории $\mathrm{C}-\mathrm{CД}$ с момента ее основания. Точно так же поступил и глава бюро премьер-министра Роман Шипош. Они оба считались ближайшими соратниками Р. Фицо [Od Fica odchádza...]. Последствием кризиса стало то, что партия была вынуждена начать функционировать в обновленном режиме. Раньше должности председателя партии и премьер-министра концентрировались в руках Р. Фицо. С марта 2018 г. в ней стали работать два центра власти: один формируется вокруг председателя партии Р. Фицо, второй - вокруг премьер-министра Пеллегрини, что приводит к возникновению конфликтов [Krempaský J., 2018]. В ходе политического кризиса резко упала электоральная поддержка партии С-СД. Если в январе 2018 г., по данным социологического агентства «Фокус», за неё было готово проголосовать 25,5\% опрошенных, то в марте 2018 г. её поддержали только 20,2 \% респондентов [Vývoj preferencií Smer-SD...]. Хотя спустя время поддержка партии стабилизировалась на уровне 21-22\% (21,7\% в декабре 2018 г.), в течение 2018 г. партия не вернулась на январский уровень [Krbatová L. 2018]. Несмотря на эту ди- 
намику, она остается партией с самой значительной поддержкой избирателей в стране. До конца 2018 г. С-СД не объявила имя кандидата на пост президента Словацкой республики, хотя проведение выборов запланировано на март 2019 г.

Ослабление партии ощущается и на фоне результатов местных выборов. C-CД сохранила первенство среди занимаемых мэрских позиций (primátor) и глав сельских органов самоуправления (starosta). Однако падение общего уровня поддержки мэров и глав сельских органов самоуправления, избранных по спискам партии, в 2014 г. с 29,11\% до 20,38 \% в 2018 г. является значительным. От партии было избрано больше чем $20 \%$ местных депутатов, что соответствует нынешнему показателю электоральной поддержки партии на общенациональном уровне. Однако этого уровня она достигла только благодаря сотрудничеству с другими партиями, особенно со Словацкой национальной партией.

C-СД в значительной степени потеряла влияние на уровне региональных центров, крупных городов. Как на региональных выборах в 2017 г., так и на муниципальных эта партия официально не заявляла о поддержке кандидатов на пост мэра Братиславы. Её кандидаты в Кошице, Прешове и Нитре потерпели поражение. Только в городе Банска Быстрица был переизбран выдвиженец от партии Ян Носко. В Тренчине партия успешно поддержала переизбрание мэра Рихарда Рыбничка. CСД сохранила поддержку только в небольших городах, на уровне районных центров и в сельской местности [Elections to the Bodies...]. Между тем она потеряла пост мэра в Гуменне - в северо-восточной Словакии, регионе традиционной электоральной поддержки левых сил [Marušiak J., 2018]. Несмотря на падение поддержки партии, она преобладает по количеству мэров и местных депутатов, избранных по партийным спискам, в сравнении с оппозиционными силами - СиС, ОЛиНЛ и ХДД. Впрочем, избиратели преимущественно поддерживали независимых кандидатов.

Таблица 2

Словакия - выборы в органы местного самоуправления в ноябре 2018 г.

\begin{tabular}{|c|c|c|c|c|}
\hline $\begin{array}{c}\text { Политическая } \\
\text { партия }\end{array}$ & $\begin{array}{c}\text { Мэры и главы } \\
\text { сельских органов } \\
\text { самоуправления }\end{array}$ & $\begin{array}{c}\text { Мэры и главы } \\
\text { сельских орга- } \\
\text { нов самоуправ- } \\
\text { ления (\%) }\end{array}$ & $\begin{array}{c}\text { Депутаты мест- } \\
\text { ных органов } \\
\text { власти }\end{array}$ & $\begin{array}{c}\text { Депутаты } \\
\text { местных ор- } \\
\text { ганов власти } \\
\text { (\%) }\end{array}$ \\
\hline Смер-СД & 592 & 20,38 & 3692 & 17,88 \\
\hline $\begin{array}{c}\text { Независимые } \\
\text { кандидаты }\end{array}$ & 1232 & 42,42 & 7301 & 35,36 \\
\hline ХДД & 157 & 5,4 & 2350 & 11,38 \\
\hline СисС & 7 & 0,24 & 110 & 0,53 \\
\hline ОЛиНЛ & 13 & 0,44 & 84 & 4,43 \\
\hline Мост-Хид & 127 & 4,37 & 915 & 6,04 \\
\hline ПВК & 115 & 3,69 & 1248 & 8,12 \\
\hline СНП & 160 & 5,50 & 1678 & \\
\hline
\end{tabular}


Источник. Elections to the Bodies of Local Self-Governments 2018. Final Results. Bratislava: Statistical Office of the Slovak Republic. Официальный сайт: http://www.volbysr.sk/en/data01.html

\section{Заключение}

Хотя выборы в органы регионального и местного самоуправления подтвердили падение динамики поддержки партии Смер-СД, она остается крупнейшим игроком среди словацких политических сил на общенациональном и на местном уровне. Опросы общественного мнения свидетельствуют, что ее ослабление не привело к росту поддержки оппозиционных партий. В течение 2018 г. она существенно не изменилась, несмотря на интенсивные протесты в городах Словакии в феврале и в марте 2018 г. [Krbatová L., 2018]. Поэтому C-СД остается крупнейшей политической силой в Словакии по сравнению с другими политическими субъектами, хотя после парламентских выборов, которые должны состояться в 2020 г., ей угрожает уход в оппозицию ввиду отсутствия коалиционных союзников.

Результаты партии на региональных выборах в ноябре 2017 г. и на местных выборах в ноябре 2018 г. подтверждают тенденцию к ослаблению ее влияния в крупных городах. Это можно наблюдать отчетливо в Братиславе, где партия отказалась от участия в политической борьбе, поскольку официально не поддержала ни одного кандидата на пост главы региона и мэра Братиславы. С-СД потерпела поражение и в других значимых городах, и её политическая поддержка все больше ориентируется на мелкие населенные пункты и сельскую местность. Уход партии из общественного дискурса подтверждает и тот факт, что вплоть до конца 2018 г. она не обозначила своего кандидата на пост президента Словацкой республики.

С 2006 г. С-СД побеждает на парламентских выборах; на региональных выборах с 2005 до 2013 гг. она непрерывно получала бо́льшую часть мест председателей органов регионального самоуправления. Ее ослабление в 2017-2018 гг. уменьшает шансы приобрести статус предоминантной партии. Несмотря на позицию лидера в парламентской гонке, она всегда, за исключением периода 2012 - 2016 гг., была вынуждена искать коалиционных партнеров. В 2010-2012 гг. С-СД даже уходила в оппозицию, потому что победа не дала возможность создать парламентское большинство с другими парламентскими силами. Партийная система Словакии содержит некоторые элементы системы предоминантной партии в основном благодаря $\mathrm{C}-\mathrm{CД}$, которая является еще и крупнейшей политической партией. Однако у нее не хватает достаточной поддержки избирателей, которая позволила бы ей приобрести статус предоминантной партии.

\section{Список литературы}

Elections to the Bodies of Local Self-Governments 2018. Final Results. Bratislava: Statistical Office of the Slovak Republic. Official website. http://www.volbysr.sk/en/data01.html

Šaradín, Pavel (2007) 'Evropské volby: vznik a vývoj teorií voleb druhého řádu', in Pavel Šaradín (ed) Evropské volby v postkomunistických zemích, pp. 9-26. Olomouc: Periplum.

Sartori, Giovanni. Parties and Party System. Framework for Analysis. Colchester: ECPR Press 2005, s. 171-178. 
Správa o krajine. Slovensko 2015. Brusel: Európska komisia 18. 3. 2015. http://ec.europa.eu/europe2020/pdf/csr2015/cr2015_slovakia_sk.pdf

The Election to the Parliament of the Slovak Republic, 10 March 2012. Assignment of seats to political parties. Bratislava: Statistical Office of the Slovak Republic. Official website. URL: http://volby.statistics.sk/nrsr/nrsr2012/sr/tab4.jsp@lang=en.htm

The Elections to the Bodies of Regional Self-Governments 2017. Final Results. Bratislava: Statistical Office of the Slovak Republic. Official website. http://volby.statistics.sk/osk/osk2017/en/data01.html

Ведерников, М (2018). Политический кризис в Словакии 2018 г.: отставка Р. Фицо и новый кабинет. П. Пеллегрини. Научно-аналитический вестник ИЕ РАН, № 2, 72-78.

\section{References}

Bariak, Ladislav ml. Minister Marek Mad’arič končí vo funkcii. Aktuality.sk, 28. 2. 2018. https://www.aktuality.sk/clanok/568279/minister-marek-madaric-konci-vo-funkcii/

Binzer Hobolt, Sara and Jill Wittrock (2011) 'The second-order election model revisited: An experimental test of vote choices in European Parliament elections', Electoral Studies, 30: 29-40.

Fico je po porážke v župných vol'bách nespokojný so svojimi l’ud'mi. Pravda, 6. 11. 2017. https://spravy.pravda.sk/domace/clanok/447266-fico-je-po-porazke-v-zupnych-volbach-nespokojny-sosvojimi-ludmi/

Kern, Miroslav - Tóda, Miroslav: Fico v Štrasburgu vysvetloval, vylúčenie Smeru z eurosocialistov stále hrozí. Denník N, 5. 10. 2015.

Koník, Juraj (2017) 'Skutočným vít’azom je KDH, po Smere je druhé najsilnejšie, SaS je hlboko za nimi', Denník N, 5 November. URL: https://dennikn.sk/932179/skutocnym-vitazom-je-kdh-po-smere-jedruhe-najsilnejsie-sas-je-hlboko-za-nimi/ (Accessed on 24 April 2018).

Krbatová, Lucia. Na úkor Smeru nik nerastie. Sme, 15. 12. 2018, s. 1-2.

Krempaský, Ján. Drucker: Pýtal som sa, prečo sme nevedeli, že Jasaň bol v kontakte s Vadalom. Sme, 29. 10. 2018. https://domov.sme.sk/c/20946921/drucker-pytal-som-sa-preco-sme-nevedeli-ze-jasan-bol-vkontakte-s-vadalom.html\#ixzz5aeLg3xvR

Mad'arič končí ako podpredseda Smeru. Hospodárske noviny, 7. 12. 2017. https://slovensko.hnonline.sk/1076039-madaric-konci-ako-podpredseda-smeru

Malová, Darina - Učeň, Peter: Slovakia. European Journal of Political Research Political Data Yearbook 52, 2013, pp. 208-216.

Malová, Darina - Učeň, Peter: Slovakia. European Journal of Political Research Political Data Yearbook 53, 2014, pp. 273-280.

Marušiak, Juraj. Vít’azstvo „strany nestraníkov“. Pravda, 12. 11. 2018, s. 45.

Matišák, Andrej. Lajčák: Nebudem kandidovat' na prezidenta. Pravda, 24. 1. 2018. https://spravy.pravda.sk/domace/clanok/455806-lajcak-nebudem-kandidovat-na-prezidenta/

Minister Mad'arič: Smer utrpel vo vol'bách prehru. Aktuality.sk, 5. 11.2017. https://www.aktuality.sk/clanok/536244/minister-madaric-smer-utrpel-vo-volbach-prehru/

Musíme zabránit' vytvoreniu ucelenej moslimskej komunity. EurActiv.sk, 7. 1. 2016. http://euractiv.sk/buducnost-eu/musime-zabranit-vytvoreniu-ucelenej-moslimskej-komunity-tvrdi-premier024719/

Od Fica odchádza jeho najbližší spolupracovník Roman Šípoš. Pravda, 2. 3. 2018. https://spravy.pravda.sk/domace/clanok/460780-od-fica-odchadza-jeho-najblizsi-spolupracovnik-romansipos/

P. Pellegrini: Smer-SD stratil dominanciu, nezačal sa však jeho úpadok. Teraz.sk, 5. 11. 2017. http://www.teraz.sk/najnovsie/p-pellegrini-smer-sd-stratil-dominanciu/290601-clanok.html.

Poslankyňa Alena Bašistová opustila stranu \#Siet'. Aktuality.sk, 3. 5. 2017. https://www.aktuality.sk/clanok/480043/poslankyna-alena-basistova-opustila-stranu-siet/

Prušová, Veronika. Najtesnejší súboj sa črtá v Žiline, za Blanára bojuje Fico, Jurinovú chcel Matovič, nik významný asi neustúpi. Denník $N, 1$ 1. 11. 2017. https://dennikn.sk/926764/najtesnejsi-suboj-sa-crta-vziline-za-blanara-bojuje-fico-jurinovu-chcel-matovic-nik-vyznamny-asi-neustupi/ 
Referendum, 7 February 2015. Final Results. Bratislava: Statistical Office of the Slovak Republic. Official website. http://volby.statistics.sk/ref/ref2015/en/data.html

Reif, Karlheinz and Hermann Schmitt (1980) 'Nine Second-Order National Elections - a Conceptual Framework For the Analysis of European Election Results', European Journal of Political Research, 8: 3-44.

Sliz, Martin. Smer nahradil Mad’ariča. Novým podpredsedom je Richard Raši. Hospodárske noviny, 9. 12. 2017. https://slovensko.hnonline.sk/1079353-priamy-prenos-smer-prejde-do-utoku-na-odporcov-kto-doteba-kamenom-my-donho-dvoma

Takáč, Adam. Kiska hovorí o rekonštrukcii vlády alebo predčasných vol'bách, Fico to odmieta. Postoj, 4. 3. 2018. https://www.postoj.sk/31181/kiska-chce-rokovat-o-rekonstrukcii-vlady-a-predcasnych-volbach

Vražda, Daniel. Smer podporí Luntera v župných vol'bách, tvrdí, že ako jediný môže porazit' Kotlebu, Denník N, 24. 8. 2017. https://dennikn.sk/862024/smer-podpori-luntera-v-zupnych-volbach-tvrdi-ze-akojediny-moze-porazit-kotlebu/.

Vývoj preferencií Smer-SD. Teraz Preferencie (november 2017 - november 2018). http://preferencie.teraz.sk/Strana/SMER-SD/1542150000

\section{Electoral crisis of Smer-SD in 2017-2018}

Author. Marušiak Ju., PhD, Senior Researcher of the Institute of Political Sciences of the Slovak Academy of Sciences. Address: Slovakia, 84104, Bratislava, Dubravská cesta, 9.E-mail: marusiak@up.upsav.sk

Abstract: Paper brings an analysis of the dynamic of electoral support of "Smer - Social Democracy“ (Direction - Social Democracy), the centre-left political party, that has the dominant position in Slovakia since the parliamentary election in 2006. Our aim is to identify, if and in which extent could this party become a pre-dominant party and in which extent it could remain the strongest political party of the country in the next period. The development of the party politics is studied in the context of so called ,second order elections", conducted in Slovakia in November 2017 (regional elections) and in November 2018 (local elections). In both cases, their result was a significant decline of the popular support of Smer-SD. However, it doesn't mean a significant strengthening of the centre-right opposition. Therefore, in spite of some signs of the intra-party crisis, Smer-SD still remains the most influential political party in Slovakia with the highest level of popular support. Smer-SD achieved some features of pre-dominant party, but it was always (except for the years 2012-2016) was forced to find some coalition partners. Therefore, it never became a full-fledged pre-dominant party and, taking into account the dynamics of its electoral support, it cannot achieve such status in a foreseeable future.

Key words: Slovakia; political parties; Social Democracy; Direction - Social Democracy (Smer-SD); second-order elections.

DOI: http://dx.doi.org/10.15211/soveurope720187589 